OPEN ACCESS

Edited by:

Hermann Einsele, Julius Maximilian University of

Würzburg, Germany

Reviewed by:

Ying-Jun Chang,

Peking University People's

Hospital, China

Hung Nguyen,

University of Central Florida,

United States

*Correspondence:

Maud D'Aveni

m.daveni-piney@chru-nancy.fr

tThese authors have contributed equally to this work

Specialty section:

This article was submitted to Alloimmunity and Transplantation,

a section of the journal

Frontiers in Immunology

Received: 05 March 2020

Accepted: 27 April 2020

Published: 22 May 2020

Citation:

D'Aveni $M$, Notarantonio $A B$, Bertrand A, Boulangé L, Pochon C and Rubio MT (2020) Myeloid-Derived

Suppressor Cells in the Context of

Allogeneic Hematopoietic Stem Cell Transplantation.

Front. Immunol. 11:989. doi: 10.3389/fimmu.2020.00989

\section{Myeloid-Derived Suppressor Cells in the Context of Allogeneic Hematopoietic Stem Cell Transplantation}

\author{
Maud D'Aveni ${ }^{1,2 *}$, Anne B. Notarantonio ${ }^{1,2 t}$, Allan Bertrand ${ }^{2}$, Laura Boulangé2 ${ }^{2}$, \\ Cécile Pochon ${ }^{1,2}$ and Marie T. Rubio ${ }^{1,2}$ \\ ${ }^{1}$ Hematology Department, CHRU Nancy, Université de Lorraine, Nancy, France, ${ }^{2}$ Université de Lorraine, UMR 7365 CNRS, \\ IMoPA, Nancy, France
}

Myeloid-derived suppressor cells (MDSCs) are innate immune cells that acquire the capacity to suppress adaptive immune responses. In the context of allogeneic hematopoietic stem cell transplantation (allo-HSCT), MDSCs (in the donor graft and in the recipient, after allo-HSCT) might mediate immune suppression through multiple mechanisms. However, it remains unclear how MDSCs can be distinguished from their normal myeloid counterparts in the hematopoietic stem cell donor graft and during immune reconstitution after allo-HSCT in the recipient. Our ability to understand their exact role in allo-HSCT is limited by the absence of a specific gene signature or surface markers for identifying MDSCs among myeloid cells and by their plasticity in different microenvironments. According to various studies, MDSCs might induce transplant tolerance and control graft vs. host disease (GVHD), but their impact on the graft vs. tumor effect (GVT) is not fully understood. In fact, we know that MDSCs commonly expand in patients with cancer, and they are thought to promote hematological malignancy progression. However, little is known about whether depleting them might be an effective strategy for enhancing GVT effects. Here, we review data published over the past 40 years on allo-HSCT to delineate the different MDSC subsets, and their abilities to induce transplant tolerance and preserve the GVT effect. This review will provide a basis for determining whether one MDSC subset might be proposed as the most appropriate candidate for cellular therapies, due to its ability to modulate GVHD.

Keywords: myeloid-derived suppressor cell, GvH disease, GvT, cellular therapy, allogeneic stem cell transplanation

\section{INTRODUCTION}

Allogeneic hematopoietic stem cell transplantation (allo-HSCT) is the only potential curative treatment for some hematopoietic malignant and non-malignant diseases. The success of this therapy is compromised by the development of life-threatening graft-vs.-host disease (GVHD). GVHD is characterized by the activation and proliferation of alloreactive donor $\mathrm{T}$ cells that subsequently attack host target organs, such as skin, gut, and liver (1). Immunosuppressive therapies administered to control GVHD are associated with an increased incidence of malignancy recurrence, because they impair the graft-vs.-tumor (GVT) effect. They are also associated with an 
increased incidence of infections. Therefore, recent strategies are considering whether regulatory cells might be good candidates for minimizing GVHD and maintaining GVT. The main candidates are: mesenchymal stromal cells (MSCs) $(2,3)$, regulatory $\mathrm{T}$ cells (Tregs) $(4,5)$, invariant Natural Killer $\mathrm{T}$ cells (iNKTs) (6), and myeloid-derived suppressor cells (MDSCs) (7).

MDSCs were first described in the peripheral blood, lymphoid organs, spleen, and tumor sites in the settings of cancer, infection, chronic inflammation, and more recently, transplantation and autoimmunity (8). Although MDSCs are barely detectable in the peripheral blood of healthy individuals, the number of circulating MDSCs increases in cancer settings, where they promote immune evasion $(9,10)$. Currently, MDSCs are attracting interest in the context of human allo-HSCT. These cells can mediate immune suppression through multiple mechanisms: by producing reactive oxygen species (ROS), depleting key amino acids required for $\mathrm{T}$ cell proliferation, and producing immunosuppressive cytokines (11). Moreover, interest has increased in identifying MDSCs in hematopoietic stem cell grafts and in the graft-recipient's peripheral blood cells. Unfortunately, in the context of allo-HSCT, MDSC phenotypes are heterogeneous in humans, and inter-study variability is high. Unlike the MDSCs described in the context of cancer (12), in the context of transplantation, we lack a harmonized or standardized definition of MDSCs. Therefore, it has been difficult to identify the best subset of MDSCs for regulating the allogeneic response. Only one study reported that CD1d expression in monocytic MDSCs was a valuable marker for selecting the subset with the highest suppressive activity (13).

This review summarizes the accumulated findings on MDSCs in the context of allo-HSCT. We examine the various MDSC phenotypes across the different studies, their immunosuppressive mechanisms, their advantages and disadvantages in GVHD and GVT, and their potential application to cellular therapy for controlling GVHD.

\section{FIRST EXPERIMENTAL EVIDENCE OF MDSCS AND CURRENT DEFINITION}

In the late 1970s, a suppressive cell population, called "natural suppressor cells" (NSC), was first identified in human, murine, and rat bone marrow, spleen, and lymphatic tissues. These cells displayed an ability to suppress T-cell responses in vivo and in vitro without regard to the typical restrictions imposed by the major histocompatibility complex (MHC) $(14,15)$. NSCs had the morphological features of immature cells in rat bone marrow, and they weakly expressed macrophage and granulocyte antigens. They were rapidly classified as cells of early monocyte lineage, and they were considered a good candidate for modulating GVHD (16).

Oseroff et al. firstly characterized NSCs in newborn and adult mice after total lymphoid irradiation (17). Then, endogenous NSCs were reported to expand in mice after bone marrow transplantation: in an irradiated syngenic mouse model (18), in MHC-matched bone marrow chimeras $(19,20)$, and in parentin-F1 bone marrow chimeras (21). These NSCs were lineage negative, that is: they did not express the typical markers for T-cell (Thy1.2 negative), B-cell (surface immunoglobulin negative), or macrophage (Mac-1 and F4/80 negative). Moreover, these NSCs appeared transiently after allo-HSCT (the number peaked in week 3), and they disappeared by week 12 in minor histocompatibility mismatched recipient mice. NSCs were derived from recipient spleens and were considered radioresistant. They inhibited T-lymphocyte proliferation after mitogenic stimulation $(19,20)$ and after allogeneic stimulation in mixed lymphocyte reaction (MLR) $(17,18,21)$. They also protected recipients against GVHD (21).

In the late 1990's, Johnson et al. demonstrated that, early after bone marrow transplantation, spleen cells collected from allogeneic chimeras contained $\mathrm{Sca}^{+}{ }^{+} \mathrm{CD}_{11 \mathrm{~b}}{ }^{+}$cells with immunosuppressive properties, through nitric oxide (NO) production (22). In another context, recipient mice that lacked SH2-containing inositol phosphatase $\left(\mathrm{SHIP}^{-/-}\right.$) displayed a reduced incidence of GVHD after allo-HSCT. This observation was correlated to an elevated number of $\mathrm{CD} 11 \mathrm{~b}^{+}$ $\mathrm{Gr}^{+}$cells in the spleen. SHIP is a $5^{\prime}$ inositol phosphatase that hydrolyzes phosphoinositol 3,4,5-trisphosphate, which regulates cell survival in myeloid cells. SHIP ${ }^{-1-}$ mice had 10- to 20-fold higher levels of $\mathrm{CD}_{11} \mathrm{~b}^{+} \mathrm{Gr}^{+}$cells with immunosuppressive properties compared to wild-type mice (23). Both those studies hypothesized that an immature $\mathrm{CD}_{11 \mathrm{~b}^{+}}$cell subset might explain the in vitro and in vivo immunosuppressive effects on alloreactive $\mathrm{T}$ cells. In the early 2000's, it was noted that NSCs shared many of the characteristics that defined MDSCs in individuals with cancer, including their myeloid origin, their accumulation after irradiation or bone marrow transplantation and their suppressive function. The accumulation of MDSCs in bone marrow transplantation recipients (allogeneic and syngenic) was related to the pro-inflammatory cytokine release that appeared during the first 2 weeks after irradiation. Moreover, this accumulation was related to the later appearance of alloreactive T cells $(24,25)$. Similarly, MDSCs were observed after donor lymphocyte infusions (DLIs). These MDSCs were further characterized as $\mathrm{Ly}_{6 \mathrm{G}}{ }^{+} \mathrm{Ly}_{6} \mathrm{C}^{+} \mathrm{CD} 34^{-} \mathrm{Sca}-1^{-} \mathrm{CD} 31^{-}$ cells, which produced NO in response to interferon- $\gamma$ (IFN- $\gamma)$ (26) (Table 1).

Currently, these cells are commonly called MDSCs, and they represent a heterogeneous group of cells. Based on the expression of CD49d, two distinct subpopulations have been described in mice: the first was the monocytic $\mathrm{CD} 49 \mathrm{~d}^{+}$subpopulation, which also displayed $\mathrm{CD}_{11 \mathrm{~b}^{+}} \mathrm{Ly}_{6 \mathrm{C}}{ }^{+} \mathrm{Ly}_{6 \mathrm{G}}{ }^{\text {low }} \mathrm{CD}_{115^{+}}$and the second was the granulocytic $\mathrm{CD}_{4} 4 \mathrm{~d}^{-}$counterpart, which displayed CD11b ${ }^{+}$Ly6C ${ }^{-}$Ly6G ${ }^{\text {high }}$ CD115- . In humans, three distinct MDSC subsets have been described, based on monocytic, granulocytic, and early-stage characteristics. They commonly do not express markers of mature myeloid and lymphoid cells (lineage negative). Thus, monocytic human MDSCs (M-MDSCs) are defined as: $\mathrm{CD}_{11 b^{+}} \mathrm{CD}_{3} 3^{+}, \mathrm{HLA}-\mathrm{DR}{ }^{\text {low } /-}$, and $\mathrm{CD} 14^{+}(27$, 28); granulocytic MDSCs (G-MDSCs) are defined as: CD11b ${ }^{+}$ $\mathrm{CD}^{+} 3^{+}, \mathrm{HLA}^{-D R}{ }^{\text {low } /-}, \mathrm{CD}^{+} 5^{+}$but CD14 ${ }^{-}$(29); and early-stage MDSCs (called e- or P-MDSCs) are defined as: $\mathrm{CD}_{3}{ }^{+}, \mathrm{CD} 11 \mathrm{~b}^{\text {low }}$ HLA-DR $^{\text {low } /-}, \mathrm{CD}_{14}^{-} \mathrm{CD} 15^{-}$. 
TABLE 1 | MDSC subsets and their immune suppressive mechanisms observed after conditioning regimen (irradiation) and after HSCT (allogenic or syngenic) in mice.

\begin{tabular}{|c|c|c|c|c|c|}
\hline References & $\begin{array}{l}\text { Mouse model } \\
\text { (DonorRecipient) }\end{array}$ & $\begin{array}{l}\text { NSC or MDSC } \\
\text { phenotype }\end{array}$ & $\begin{array}{l}\text { Day (D) of first } \\
\text { detection }\end{array}$ & $\begin{array}{l}\mathrm{T} \text { cell proliferation } \\
\text { assay }\end{array}$ & Mechanisms \\
\hline Oseroff et al. (17) & BALB/C (after TLI) & $\begin{array}{l}\text { Non T cell, non B cell, non } \\
\text { macrophage } \\
\text { (Thy1.2-, 2C2-, Mac1-, F4/80-) }\end{array}$ & $\begin{array}{l}\mathrm{D}+5 \\
\text { (after TLI) }\end{array}$ & $\searrow M L R$ & $?$ \\
\hline Sykes et al. (18) & $\begin{array}{l}\text { B10B10 } \\
\text { B10.D2B10.D2 } \\
\text { (syngenic) }\end{array}$ & $\begin{array}{l}\text { Non-T cell, non-B cell, non } \\
\text { macrophage }\end{array}$ & $\begin{array}{l}\text { Early weeks (after } \\
\text { HSCT) }\end{array}$ & $\searrow C M L$ & $?$ \\
\hline Holda et al. (19) & $\begin{array}{l}\text { B10.D2BALB/C } \\
\text { B10.D2B10D2F1 } \\
\text { (MiHAgs) }\end{array}$ & Mac1-, Sca-1-, Thy1- & $\begin{array}{l}\mathrm{D}+7 \\
\text { (after alloHSCT) }\end{array}$ & $\begin{array}{l}\searrow \text { mitogenic } \\
\text { response } \\
\searrow \text { MLR }\end{array}$ & $?$ \\
\hline Maier et al. (20) & $\begin{array}{l}\text { B10.D2BALB/C } \\
\text { (MiHAgs) }\end{array}$ & $\begin{array}{l}\text { Thy } 1.2-\text {, IgS- } \\
\text { Non adherent to plastic plate }\end{array}$ & $D+10$ & $\begin{array}{l}\searrow \text { mitogenic } \\
\text { response }\end{array}$ & $\begin{array}{l}\text { ? } \\
\text { (inducible } \\
\text { mechanism) }\end{array}$ \\
\hline Sykes et al. (21) & $\begin{array}{l}\text { B10 +/- B10.D2B10 } \\
\text { (syngenic +/- mixed with } \\
\text { H2 disparity) }\end{array}$ & $\begin{array}{l}\text { Non-T cell, non-B cell, non } \\
\text { adherent, asialo GM1-negative } \\
\text { syngenic to the recipient }\end{array}$ & $\begin{array}{l}>\mathrm{D}+8 \\
\text { After allo and } \\
\text { syngenic HSCT) }\end{array}$ & $\searrow C M L$ and MLR & $?$ \\
\hline Johnson et al. (22) & $\begin{array}{l}\text { B10.BRB10.BR (syngenic) } \\
\text { B6129F2 or B10.BR AKR } \\
\text { (complete H2 disparity) }\end{array}$ & $\begin{array}{l}\text { Thy 1.2-, IgS- } \\
\text { Mac1 low, Sca-1+ }^{\text {low }}\end{array}$ & $D+10$ & $\searrow M L R$ & iNOS \\
\hline Ghansah et al. (23) & $\begin{array}{l}\text { C3H AKR } \\
\text { (MiHAgs) }\end{array}$ & $\begin{array}{l}\text { CD11b+/Ly6G+/Ly6C+/CD14- } \\
\text { /F4/80-/CD11c- }\end{array}$ & $D+21$ & ?MLR & NO \\
\hline Luyckx et al. (24) & $\begin{array}{l}\text { B6 B6D2F1 } \\
\text { (partial H2 disparity) }\end{array}$ & $\mathrm{Gr}-1^{+} / \mathrm{CD} 11 \mathrm{~b}^{+}$ & $D+21$ & $\searrow M L R$ & iNOS? \\
\hline Wang et al. (25) & $\begin{array}{l}\text { B6B6 (syngenic) } \\
\text { B6BALB/C } \\
\text { (complete H2 disparity) }\end{array}$ & $\mathrm{Gr}-1^{+} / \mathrm{CD} 11 \mathrm{~b}^{+}$ & $D+14$ & $\searrow$ MLR & $\begin{array}{l}\text { Arg-1 } \\
\text { ROS }\end{array}$ \\
\hline
\end{tabular}

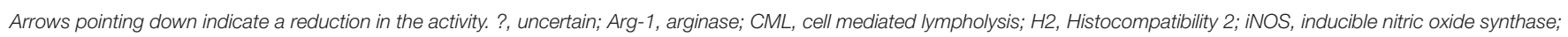
MDSC, myeloid derived suppressive cells; MiHAgs, Minor Histocompatibility Antigens; MLR, mixed lymphocyte reaction; NO, nitric oxide; ROS, reactive oxygen species.

Mouse models and MHC haplotype:

$H 2^{b}$ : B6 (C57BL/6), B10: C57BL/10SnJ (a substrain of C57BL) and B6129F2.

$H 2^{d}: B A L B / C, B 10 . D 2: B 10 . D 2 / n S n$ and DBA 2 .

$H 2^{k}: A K R, B 10 . B R$, and $C 3 H$.

$H 2^{b d}: B 6 D 2 F 1(C 57 B L / 6 \times D B A / 2)$ and B10D2F1 (B10.D2 × BALB/C).

\section{ROLES OF MDSCS AND MECHANISMS OF ACTION}

\section{Murine Models of GVHD}

In the context of allo-HSCT, MDSCs are mainly defined by their capacity to inhibit the proliferation of allogeneic $T$ cells. To date, these immunosuppressive properties have been attributed to four main mechanisms demonstrated in vitro and in vivo, including: NO production; arginase 1-mediated L-arginine depletion; indoleamine 2,3-dioxygenase (IDO)-mediated tryptophan (an essential amino acid) conversion; and $\mathrm{T}$ regulatory lymphocyte (Treg) induction (Figure 1). Of note, the ROS mechanism of immunosuppression, which was antagonized by adding catalase, was only described once in vitro (25).

Experimentally, the immunoregulatory role of $\mathrm{NO}$ was established by showing that immunosuppression could be reversed with NO synthase (NOS) inhibitors, such as NGmonomethyl-1-arginine monoacetate, in vitro. $\mathrm{NO}$ is known to be a negative regulator of intracellular-signaling protein cascades downstream of the interleukin-2 (IL-2) receptor (30, 31). NO blocks the phosphorylation and activation of several signaling proteins, including Janus-activated kinases 1 and 3 , signal-transducer and activator of transcription-5, extracellularsignal-regulated kinase, and protein kinase B (32). NO affects the stability of IL-2 mRNA and the release of IL-2 from activated lymphocytes (33). High NO concentrations also induce T-cell apoptosis through various mechanisms, including accumulation of the tumor-suppressor protein, p53; signaling through Fas or tumor necrosis factor (TNF)-receptor family members; or signaling through caspase-independent pathways (34). The main MDSC subset capable of producing NO is the M-MDSC subset $\left(\mathrm{CD} 11 \mathrm{~b}^{+}\right.$Ly6C $\left.\mathrm{C}^{\text {high }} \mathrm{Ly} 6 \mathrm{G}^{\text {low }}\right)$. We previously demonstrated that, within the M-MDSC population, there was a highly immunosuppressive subpopulation of cells that expressed CD34; these cells were called CD34 ${ }^{+}$monocytes (35). In vitro, $\mathrm{CD}^{+}{ }^{+}$monocytes required T-cell-mediated IFN- $\gamma$ stimulation to produce $\mathrm{NO}$ and to inhibit $\mathrm{T}$ cell activation and proliferation. In vivo, adoptive therapy with $\mathrm{CD} 34^{+}$monocytes protected mice from acute GVHD.

Depletion of L-arginine with arginase 1 inhibits $\mathrm{T}$-cell proliferation by inhibiting $\mathrm{T}$-cell expression of the $\mathrm{CD} 3 \zeta$ chain, the cell-cycle regulator, cyclin D3, and cyclin-dependent kinase 4 (36). Recently, Highfill and colleagues demonstrated that MDSCs generated from murine bone marrow cells and 


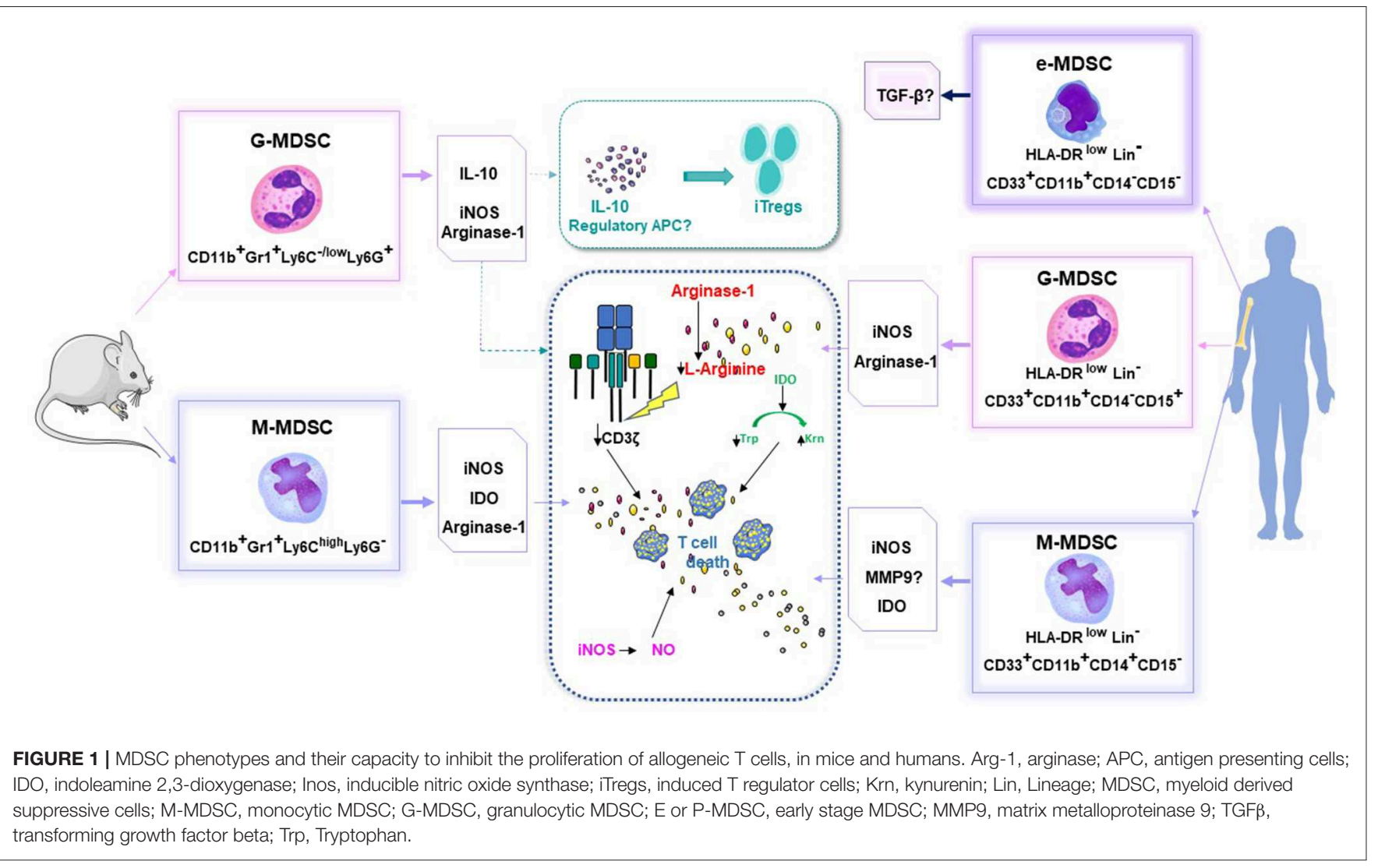

cultured with granulocyte colony-stimulating factor (G-CSF) and granulocyte-monocyte colony-stimulating factor (GM-CSF) induced arginase-1 activity, which depleted T-cell L-arginine. This depletion resulted in the inhibition of allogeneic T-cell responses, both in vitro and in vivo. The addition of IL-13 to bone marrow cultures resulted in up-regulating arginase-1 activity, which then increased the suppressive activity of this MDSC subset (37).

IDO is a potent immunoregulatory enzyme that converts the essential amino acid, tryptophan, into catabolic products, collectively known as kynurenines. Joo et al. reported that IFN- $\gamma$ treatment induced functional IDO activity in MDSCs

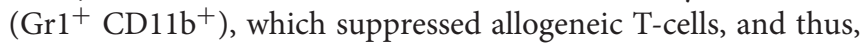
modulated GVHD (38).

IL-10 is a potent anti-inflammatory cytokine that plays a role in interactions between neutrophils and Tregs (39). Conventional $\mathrm{T}$ cells can be converted to Tregs as a consequence of antigen exposure in the periphery, under inflammatory and non-inflammatory (TGF $\beta$, IL-10) conditions (40). After allogeneic HSCT, peripheral Tregs emerge in vivo, due to IL-10 production by G-MDSCs $(41,42)$. Induced peripheral Tregs are involved in the control of immunity at sites of inflammation, particularly at mucosal surfaces. More recently, natural Treg proliferation was demonstrated through a mechanism that depended on their cell-cell contact with MDSCs that expressed the Programmed Death-1 ligand (PDL1) (43).
In the context of chronic GVHD, the role of MDSCs has been poorly explored. In a mouse model of chronic GVHD, it was reported that ex vivo cultured MDSCs could modulate chronic GVHD presumably by preventing thymic tissue damages and reducing the percentages of CD4 $+\mathrm{T}$ cells that produced IL-17 (Th17 cells) and IL-4 (Th2 cells) (44).

\section{Human allo-HSCT and GVHD (Table $2+$ Figure 1)}

MDSCs have been observed in grafts of G-CSF-mobilized peripheral blood hematopoietic stem cell (PBSCs) (45). The presence of some MDSC subsets in hematopoietic stem cell grafts has been correlated with a lower incidence of acute GVHD. For instance, common monocytic MDSCs (defined as $\mathrm{Lin}^{-}$ HLA-DR ${ }^{\text {low }} /{ }^{-} \mathrm{CD}_{11 b^{+}} \mathrm{CD}_{3}{ }^{+} \mathrm{CD}^{+} 4^{+}$) (46); CD34 ${ }^{+}$monocytic MDSCs (Lin ${ }^{-}$HLA-DR ${ }^{\text {low }} /{ }^{-} \mathrm{CD}_{11 b^{+}} \mathrm{CD} 3^{+} \mathrm{CD}^{+}{ }^{+}$) (35); and early-stage MDSCs (HLA-DR ${ }^{-}{ }^{\text {low }} \mathrm{CD} 3^{+} \mathrm{CD}^{-} 4^{-} \mathrm{CD}^{-}$) $(47)$ were correlated with a lower incidence of acute GVHD in HLAmatched and haplo-identical HSCT settings (48). Moreover, G-CSF-primed bone marrow grafts contained higher levels of Lin $^{\text {low/- }} \mathrm{HLA}^{-D R^{-}} \mathrm{CD}^{+} 3^{+} \mathrm{CD} 1 \mathrm{~b}^{+}$MDSCs, compared to PBSC grafts, and the G-CSF primed bone marrow grafts were associated with improved GVHD-free survival (49).

After an allo-HSCT, MDSC recovery during immune reconstitution and its clinical relevance have not been fully determined. MDSCs were first observed in recipients that developed acute GVHD. Those MDSCs were defined as a myeloid 
TABLE 2 | MDSCs in the setting of human allogeneic HSCT.

\begin{tabular}{|c|c|c|c|c|c|c|c|c|c|c|}
\hline \multirow[t]{2}{*}{ References } & \multicolumn{2}{|c|}{ Type of MDSC } & \multirow[t]{2}{*}{ Early Stage } & \multirow{2}{*}{$\begin{array}{l}\text { Before/after } \\
\text { HSCT }\end{array}$} & \multirow{2}{*}{$\begin{array}{l}\text { Immunosuppressive } \\
\text { mechanism }\end{array}$} & \multirow{2}{*}{$\begin{array}{l}\text { Acute } \\
\text { GVHD }\end{array}$} & \multirow{2}{*}{$\begin{array}{l}\text { Chronic } \\
\text { GVHD }\end{array}$} & \multirow[t]{2}{*}{ os } & \multirow[t]{2}{*}{ NRM } & \multirow[t]{2}{*}{ EFS } \\
\hline & Monocytic & Granulocytic & & & & & & & & \\
\hline \multirow[t]{2}{*}{ Luyckx et al. (45) } & $\begin{array}{l}\mathrm{Lin}^{-}, \mathrm{HLA}^{-D R^{-}} \\
\mathrm{CD} 11 \mathrm{~b}^{+} \mathrm{CD}^{+} 3^{+}\end{array}$ & $\begin{array}{l}\mathrm{Lin}^{-}, \mathrm{HLA}^{-\mathrm{DR}}{ }^{-} \\
\mathrm{CD} 11 \mathrm{~b}^{+} \mathrm{CD}^{+}{ }^{+}\end{array}$ & & Before & $?$ & ND & ND & ND & ND & ND \\
\hline & $\mathrm{CD}^{+} 4^{+} \mathrm{CD}^{-} 5^{-}$ & $\mathrm{CD}^{+} 5^{+} \mathrm{CD} 14^{\text {low }}$ & & & & & & & & \\
\hline $\begin{array}{l}\text { Vendramin et al. } \\
\text { (46) }\end{array}$ & $\begin{array}{l}\mathrm{Lin}^{-}, \mathrm{HLA}^{-} \mathrm{DR}{ }^{-} \\
\mathrm{CD} 11 \mathrm{~b}^{+} \mathrm{CD}^{+} \\
\mathrm{CD}^{+} 4^{+}\end{array}$ & & & Before & $?$ & $\searrow$ & ND & ND & ND & ND \\
\hline D’Aveni et al. (35) & $\begin{array}{l}\mathrm{Lin}^{-}, \mathrm{HLA}^{-D R}{ }^{-} \\
\mathrm{CD}^{+} 4^{+} \\
\mathrm{CD}^{\prime} 1 b^{+} \mathrm{CD}^{+} 3^{+} \\
\mathrm{CD}^{+} 4^{+}\end{array}$ & & & Before & iNOS & $\searrow$ & ND & ND & ND & ND \\
\hline Wang et al. (47) & & & $\begin{array}{l}\text { HLA-DR }^{-} \\
\mathrm{CD}^{-} 3^{+} \mathrm{CD}^{-} 6^{-}\end{array}$ & Before & TGF $\beta ?$ & $\searrow$ & $\searrow$ & $=$ & $=$ & $=$ \\
\hline Lv et al. (48) & $\begin{array}{l}\mathrm{Lin}^{-}, \mathrm{HLA}^{-D R^{-}} \\
\mathrm{CD} 11 \mathrm{~b}^{+} \mathrm{CD}^{+} 3^{+} \\
\mathrm{CD}^{+} 4^{+}\end{array}$ & & $\begin{array}{l}\mathrm{Lin}^{-}, \mathrm{HLA}^{-} \mathrm{DR}{ }^{-} \\
\text {CD11blow } \\
\mathrm{CD}^{+} 3^{+} \\
\mathrm{CD}^{-} 4^{-} \mathrm{CD}^{-} 5^{-}\end{array}$ & Before & $?$ & $\searrow$ & $\searrow$ & $=$ & $=$ & $=$ \\
\hline Fan et al. (49) & Total MDSCs: & Lin $^{-}, \mathrm{HLA}^{-} \mathrm{DR}^{-}$, & $\mathrm{CD}_{11} \mathrm{~b}^{+} \mathrm{CD}^{+}{ }^{+}$ & Before & $?$ & $\searrow$ & $\searrow$ & $=$ & $=$ & $=$ \\
\hline $\begin{array}{l}\text { Mougiakakos et al. } \\
\text { (50) }\end{array}$ & HLA-DR ${ }^{-}$CD14+ & & & After & IDO & $\nearrow$ & ND & ND & ND & ND \\
\hline Guan et al. (51) & $\begin{array}{l}\mathrm{CD}^{+} 3^{+} \mathrm{CD}^{-} 5^{-} \\
\mathrm{CD}^{+} 4^{+} \mathrm{HLA}^{-} \mathrm{DR}^{-}\end{array}$ & $\begin{array}{l}\mathrm{CD}^{+} 3^{+} \mathrm{CD}^{+} 5^{+} \\
\mathrm{CD} 6 \mathrm{~b}^{+}\end{array}$ & & After & $\begin{array}{l}\text { Arg-1 iNOS } \\
\text { (for G-MDSCs) }\end{array}$ & $=$ & ND & ND & ND & ND \\
\hline Kim et al. (52) & $\begin{array}{l}\mathrm{CD}^{+} 4^{+} \\
\mathrm{HLA}^{-} \mathrm{DR}^{-}\end{array}$ & & & After & $?$ & $\searrow$ & ND & ND & $=$ & $=(\nearrow \mathbf{R I})$ \\
\hline Lee et al. (53) & $\begin{array}{l}\mathrm{CD}^{+} 4^{+} \\
\mathrm{HLA}^{-\mathrm{DR}^{-}}\end{array}$ & & & After & MMP9 & $=$ & ND & $=$ & $\searrow$ & $\searrow$ \\
\hline
\end{tabular}

Arrows indicate increases (pointing up) or decreases (pointing down) in the activity or effect (according to the number of MDSC); =, indicates no change observed; ?, unknown;

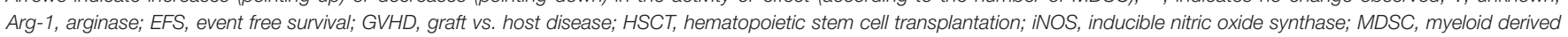
suppressive cells; MMP, matrix metalloproteinase 9; ND, not done; NRM, non relapse mortality; OS, overall survival.

circulating cell subset (HLA-DR low/- $\left.\mathrm{CD} 14^{+}\right)$endowed with in vitro suppressive properties through $\operatorname{IDO}(50,51)$. Furthermore, M-MDSCs (HLA-DR low/- $\mathrm{CD}^{+} 3^{+} \mathrm{CD} 14^{+}$) and G-MDSCs (HLA-DR ${ }^{-/ \text {low }} \mathrm{CD}^{3} 3^{+} \mathrm{CD} 5^{+} \mathrm{CD} 6 \mathrm{~b}^{+}$) have been isolated from recipients early after transplantation (within 3 months). Those cells could suppress third-party CD4 T-cell proliferation and Th1 differentiation, and they promoted Treg development (51). Increased levels of circulating MDSCs have also been described in patients treated with extracorporeal photopheresis for acute and chronic GVHD (54). Extracorporeal photopheresis was associated with an increase in circulating MDSCs, reduction in $\mathrm{CD} 19^{\text {high }} \mathrm{CD} 20^{\text {high }} \mathrm{B}$ cells, and reductions in the expression of CD38 and the BAFF-receptor (55). Unfortunately, the potential mechanisms that gave rise to these observations and the correlations between MDSCs and B cells in the context of chronic GVHD remain unknown.

Prospective studies have attempted to identify which MDSC subsets in recipients could impact post-transplantation outcomes, including overall survival (OS), non-relapse mortality (NRM), event-free survival (EFS), and acute and chronic GVHD. The common findings of those studies were:

- early expansion of G-MDSCs was not correlated with posttransplantation outcomes $(52,53)$.
- early expansion of M-MDSCs was associated with a higher early infection incidence, a higher NRM, and a lower EFS (and/or higher relapse incidence $=\mathrm{RI}$ ), but did not affect OS.

- early expansion of M-MDSCs was not associated with acute GVHD in patients that received transplants from siblings or matched unrelated donors $(51,53)$. Lower expansion of M-MDSCs after allo-HSCT was associated with severe acute GVHD in a cohort of patients that received transplants from siblings, matched unrelated donors, haploidentical-related donors, and double cord donors (52) (Table 2).

To summarize these different studies, M-MDSCs that circulate in the peripheral blood of human recipients early after transplantation can be considered as biomarkers of inflammation, and they can predict some post-transplantation outcomes (infections, GVHD, NRM). However, these findings require validation in larger cohorts.

\section{Impact of MDSCs on the GVT Effect}

In mice, when MDSCs generated in vitro were infused to treat severe acute GVHD, the GVT effect was conserved (37). This effect was observed even when the adoptive transfer was performed with MDSCs freshly isolated from tumor-bearing mice. This phenomenon was explained by the observation 
that MDSCs spare cytotoxic T lymphocytes (NKG2D ${ }^{+}$CD8 T cells), which play an important role in the retention of GVT activities (56). Moreover, it was demonstrated that CD4 T cells were more susceptible to suppression by MDSCs, and the development of $\mathrm{NKG}_{2} \mathrm{D}^{+} \mathrm{T}$ cell populations was associated with the expression of NKG2D ligands on MDSCs. In another mouse model, MDSCs attenuated GVHD in an IL-10 and Treg-dependent manner; (42) indeed, it was previously shown that Tregs could preserve the GVT effect in mice (57). In some studies, post-transplant chemotherapies [bendamustine (58) and cyclophosphamide (59)] induced $\mathrm{CD}_{11 b^{+}} \mathrm{Gr}^{+}$cells which probably played role in transplant tolerance induction. However, the effect of MDSCs on GVT in the model of posttransplant bendamustine was unclear, because chemotherapy can also improve tumor control (58).

In humans, MDSCs have been related to worse outcomes in hematological malignancies $(60,61)$; therefore, MDSCs were suspected to be involved in relapses after allo-HSCT. However, in the allo-HSCT setting, only a few prospective studies have reported a significantly higher probability of relapse in patients with higher M-MDSC frequencies than other patients, in the 30 days following allo-HSCT $(52,53)$. Other studies suggested that MDSCs preserved the GVT effect $(26,56)$. In a recent study, G-MDSCs derived from GCSF-mobilized donors inhibited in vitro NK cytolytic activity through an IDO and PGE2 mechanism. Those findings suggested that G-MDSCs had a potent inhibitory effect on the antileukemia activity of donor mature NK cells in recipients (62). For instance, DLIs, which are performed to control hematological malignancies, have been tested with or without G-CSF treatment. The DLIs derived from PBSCs collected after G-CSF treatment favored the conversion to full donor chimerism, despite the higher content of $\mathrm{M}$ MDSCs. Moreover, G-CSF-treated DLIs were associated with lower cumulative incidences of relapse and disease progression, and did not significantly increase the cumulative incidence of GVHD (63). Additionally, during the first 100 days after alloHSCT, the number of MDSCs in peripheral blood was correlated with the occurrence of severe acute GVHD, but not with an increased risk of malignancy recurrence (64). These observations suggested that MDSCs might not inhibit the GVT effect.

\section{ARE MDSCS OF INTEREST AS A CELLULAR THERAPY? Generation of MDSCs in Mouse Models (Table 3)}

MDSCs can be successfully generated in mice. This was first established with CpG. CpG was administered either alone or emulsified in incomplete Freund's adjuvant. This treatment caused an accumulation of double-positive $\mathrm{CD}_{11 \mathrm{~b}^{+}} \mathrm{Gr}-1^{+}$cells in the donor's peripheral blood and spleen. Splenic CD11b ${ }^{+}$ $\mathrm{Gr}^{+}$cells isolated from treated mice efficiently suppressed alloreactivity in an MLR in vitro, and they prevented GVHD in vivo (65). Later, Joo et al. administered G-CSF to B6 mice. They observed that the mobilized donor graft spleen used for hematopoietic stem cell transplantation contained a large number of immature Gr-1 ${ }^{+} \mathrm{CD}_{11 \mathrm{~b}^{+}}$myeloid cells. These cells suppressed alloreactive donor $\mathrm{T}$ cells, which resulted in the inhibition of acute GVHD through an IDO-independent mechanism (38). MacDonald et al. described cells that were induced by progenipoietin-1 (a synthetic G-CSF/Flt-3 ligand molecule). These cells can (retrospectively) be considered MDSCs, because they promoted transplant tolerance by inducing MHC class II-restricted, IL-10-secreting, antigen-specific Tregs (41). In another experimental model, MDSCs were induced after culturing bone marrow cells for 4 days with G-CSF and GM-CSF (37). The resulting CD11b ${ }^{+} \mathrm{Ly}_{6} \mathrm{G}^{\text {low }} \mathrm{Ly}_{6 \mathrm{C}^{+}}$MDSCs could inhibit allogeneic $\mathrm{T}$-cell responses in vitro and in vivo by inducing arginase- 1 activity. Addition of exogenous IL-13 in the culture produced a subset of MDSCs (MDSC-IL-13) with greater immunosuppressive potential, due to an up-regulation of arginase-1. MDSC-IL-13 cells migrated to sites of allopriming, where they limited alloreactive donor T-cell proliferation, activation, and pro-inflammatory cytokine production (37). These cells had potent suppressive activity, which resulted in the prevention of acute GVHD lethality. Transplantation of these generated MDSCs inhibited GVHD, but not the antitumor cytotoxicity of alloantigen-specific $\mathrm{T}$ cells. Moreover, these MDSCs skewed the allogeneic T cell profile toward type- $2 \mathrm{~T}$ cells, which upregulated T helper 2 (Th2)-specific cytokines (66). Because G-CSF-treated PBSCs are currently used as a source of hematopoietic stem cells in humans, two research teams evaluated the impact of G-CSF-induced MDSCs present in the donor graft. They showed that both G-MDSCs and MMDSCs induced by G-CSF could reduce acute GVHD in a Treg-dependent manner, through different mechanisms $(35,42)$ (Table 2).

\section{Generation of MDSCs in Humans}

Successful treatments with ex vivo cultured MDSCs have been reported in mouse models, but what do we know about human GVHD? Generating MDSCs for clinical applications might be difficult, because MDSCs represent a rare subpopulation of myeloid cells. A Korean research team proposed to expand MDSCs from one cord blood unit (CBU). They investigated which cytokine combinations (GM-CSF/SCF) could efficiently expand and differentiate human MDSCs from a culture of CD34 ${ }^{+}$cells. They showed that human MDSCs could be expanded on a large scale, compatible with clinical applications. They produced up to $10^{8}$ MDSCs (HLA-DR ${ }^{\text {low }} \mathrm{CD} 11 \mathrm{~b}^{+} \mathrm{CD} 33^{+}$) from $1 \mathrm{CBU}$. Infusion of these expanded MDSCs (i.e., thirdparty cells) significantly reduced GVHD scores, which prolonged survival in a NOD-scid IL2rg ${ }^{\text {null }}$ (NSG) xenogeneic mouse model of GVHD (67). Unfortunately, producing sufficient MDSCs required 6 weeks of continuous culture, which might be too long for their use as a treatment for severe acute GVHD. In fact, the most effective approaches for GVHD are those that dampen T-cell responses early after transplantation (prophylaxis). Once alloreactive $\mathrm{T}$ cells have begun to contribute to organ injury, it is probably too late to propose cellular therapy. Because most MDSCs do not survive after freeze-thawing, a biobank of these cells is not relevant, and MDSC generation in humans is a difficult avenue of research. To generate a rapidly available cellular 
TABLE 3 | MDSCs (cellular therapy) in HSCT mouse models: induction, mechanisms of action, and impact on GVHD, GVL, and OS.

\begin{tabular}{|c|c|c|c|c|c|c|c|}
\hline References & MDSC phenotype & $\begin{array}{l}\text { Factors that induced } \\
\text { MDSCs }\end{array}$ & $\begin{array}{l}\text { T cell proliferation } \\
\text { in MLR }\end{array}$ & $\begin{array}{l}\text { Immunosuppressive } \\
\text { mechanisms }\end{array}$ & $\begin{array}{l}\text { Acute } \\
\text { GVHD }\end{array}$ & GVL & os \\
\hline Morecki et al. (65) & $\begin{array}{l}\mathrm{Gr}^{+}{ }^{+} \mathrm{CD} 11 b^{+} \\
\mathrm{CD} 11 \mathrm{c}^{-} \mathrm{CD}^{-} 4^{-} \mathrm{F} 4 / 80^{-}\end{array}$ & CpG+IFA & $\searrow$ & $(\mathrm{IL}-6, \mathrm{IL}-10, \mathrm{IFN}-\gamma) ?$ & $\searrow$ & ND & $\nearrow$ \\
\hline Joo et al. (38) & $\mathrm{Gr}-1^{+} \mathrm{CD} 11 \mathrm{~b}^{+} \mathrm{Ly}_{6 \mathrm{C}}+$ & G-CSF & $\searrow$ & IDO & $\searrow$ & ND & $\nearrow$ \\
\hline $\begin{array}{l}\text { MacDonald et al. } \\
\text { (41) }\end{array}$ & $\begin{array}{l}\text { GM cells } \\
\text { CD11b+ Gr1 low }\end{array}$ & G-CSF+FLT3-L & & $\begin{array}{l}\text { IL-10 } \\
\searrow \text { Treg }\end{array}$ & $\searrow$ & ND & $\nearrow$ \\
\hline Highfill et al. (37) & $\begin{array}{l}\text { CD11b+ Ly6Glow } \text { Ly6C }^{+} \\
\text {IL-4R } \alpha^{+} \text {F4/80+ }\end{array}$ & $\begin{array}{l}\text { G-CSF+GM-CSF } \\
+/-I L-13\end{array}$ & $\searrow$ & Arg-1 & $\searrow$ & $=$ & $\nearrow$ \\
\hline $\begin{array}{l}\text { Messman et al. } \\
\text { (66) }\end{array}$ & $\begin{array}{l}\mathrm{Gr}-1^{+} \mathrm{CD} 11 \mathrm{~b}^{+} \mathrm{CD} 115^{+} \\
\mathrm{IL}-4 \mathrm{R} \alpha^{+}\end{array}$ & $\mathrm{G}-\mathrm{CSF}+\mathrm{GM}-\mathrm{CSF}$ & $\searrow$ & Th2 & $\searrow$ & $=$ & $\nearrow$ \\
\hline D’Aveni et al. (35) & $\begin{array}{l}\mathrm{CD} 34^{+} \mathrm{CD} 11 \mathrm{~b}^{+} \mathrm{CD}^{+}{ }^{+} \\
\mathrm{CD} 115^{+} \mathrm{Ly}^{+} \mathrm{C}^{+}\end{array}$ & G-CSF & $\searrow$ & $\begin{array}{l}\text { iNOS } \\
\text { Tregs }\end{array}$ & $\searrow$ & ND & $\nearrow$ \\
\hline Perobelli et al. (42) & CD11b+ Ly6Gigh Ly6C- & G-CSF & ND & $\begin{array}{l}\mathrm{IL}-10 \\
\text { Tregs }\end{array}$ & $\searrow$ & $=$ & $\nearrow$ \\
\hline
\end{tabular}

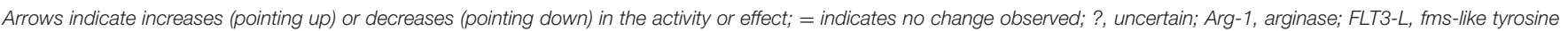

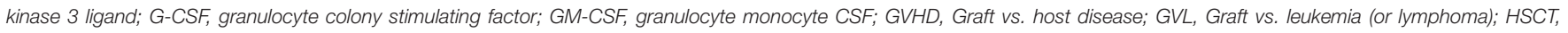

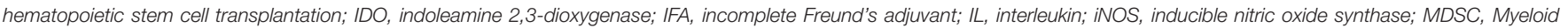
derived suppressive cells; MLR, Mixed lymphocyte reaction; ND, not done; OS, Overall survival; Th2, Helper T cell type 2.

therapy, a donor apheresis sample was sorted, and hematopoietic progenitor cells $\left(\mathrm{CD} 34^{+}\right.$cells) were selected and frozen. At the right moment, $\mathrm{CD} 34^{+}$cells were thawed and cultured for 20 days with stem cell factor, thrombopoietin, fms-like tyrosine kinase 3 ligand, GM-CSF, and IL-6. This treatment generated both M-MDSCs and G-MDSCs (68). However, these cells were only tested in vitro. Alternatively, Bonnotte's team proposed to generate ex vivo human suppressor cells of monocytic origin (HuMoSCs), rather than from hematopoietic progenitor cells. These HuMoSCs were obtained after 7 days of culture with GMCSF and IL-6. Because they were obtained from mature cells, they could not be called MDSCs, but they promoted, in vivo, the development of a CD8 T lymphocyte subset that expressed FOXP3, which induced peripheral tolerance. Interestingly, these cells could be infused to prevent GVHD on day 7 after transplantation. Alternatively, they could be frozen, then thawed at the precise moment they were needed (69). Unfortunately, little is known about the in vivo viability, trafficking, and expansion of these cultured cells.

\section{DISCUSSION AND FUTURE CONSIDERATIONS}

MDSCs represent a diverse population of immature myeloid cells that are currently well-described in the context of allogeneic stem cell transplantation. MDSC properties have been described according to observations at different times during the transplantation procedure: in the donor graft after mobilization, in the recipient after a conditioning regimen, and during the reconstitution of the donor-derived immune system. Flow cytometry studies have analyzed MDSCs in the graft and in recipient blood samples during post-transplantation immune recovery; however, their role is not fully understood. They represent a biomarker of inflammation, but their immunosuppressive properties are not always maintained; thus, these properties are likely to depend on the context.

MDSCs were first described as highly immunosuppressive cells derived from radioresistant recipient cells. However, recent data have suggested that the intestinal microbiota might provide new avenues of researches on how MDSCs might be induced and modulated after a conditioning regimen. We know that conditioning regimens induce tissue damage, which allows bacterial products to translocate from the skin and mucosa into the blood, where they can activate immune cells. After conditioning, lipopolysaccharide (LPS) mediates activation of the pathway involving Toll Like Receptor 4 (TLR4)-myeloid differentiation primary response gene 88 (MyD88)- nuclear factor-kappa B (NF- $\mathrm{B})$. In a recent study, recipients that received MyD88-deficient bone marrow cell transplantations developed severe intestinal GVHD associated with an insufficient expansion of donor MDSCs. That result suggested that intestinal microbiota might regulate MDSC induction through the TLR/MyD88 pathway (70). In humans, patients that received broad spectrum antibiotics (carbapenem) developed dysbiosis of the intestinal microbiota. This condition was associated with reduced recovery of E- and M-MDSCs and an increase in the cumulative incidence of intestinal GVHD (71). Those findings suggested that, early after conditioning, the TLR/Myd88 pathway might first stimulate (signal 1) Nlrp3 inflammasome, which might induce the generation of MDSCs.

On the other hand, the conditioning regimen also provides a second stimulus (signal 2), through damaged tissues, which cause the release of damage-associated molecular pattern (DAMP) molecules. The release of DAMPs in the conditioning phase can activate the Nlrp3 inflammasome in recipient cells, and this activation correlated to an increased risk of severe GVHD (72). The main endogenous DAMP molecule, Adenosine-5'triphosphate acts as a ligand for the P2X7 receptor (73). Activation of the $\mathrm{P} 2 \mathrm{X} 7$ receptor was shown to be a critical 
step in the pathogenesis of GVHD (74). Koehn et al. recently demonstrated that the binding of ATP to the P2X7 receptor could induce the assembly and activation of the Nlrp3 inflammasome. Full activation of the Nlrp3 inflammasome led to MDSCs differentiation and the loss of suppressor function (75). Thus, MDSCs that are induced early after conditioning could rapidly differentiate and lose their immunosuppressive function after allogeneic HSCT. Indeed, pharmacologic agents that targeted Nlrp33 and the P2X7 receptor provided significantly higher survival, due to a lower incidence of $\operatorname{GVHD}(7,76)$.

Strikingly, excessive production of mitochondrial ROS molecules was observed during conditioning; this represents another second stimulus (signal 2) of the Nlrp3 inflammasome (77). In hematology, as in oncology, the metabolism of MDSCs in the tumor microenvironment is commonly described as highly active. These MDSCs produce high levels of cytosolic ROS, due to the action of NADPH oxidase (NOX2). This environment appears to maintain MDSCs in an undifferentiated state with immunosuppressive properties (78). In allogeneic HSCT, NOX2-mediated ROS production in MDSCs has been poorly described (25). However, excessive oxidative stress, due to both mitochondrial and cytosolic ROS production, could compromise redox homeostasis in MDSCs. This condition can activate a nuclear factor called erythroid-derived 2-like 2 (Nrf2), which regulates an endogenous antioxidant mechanism that is involved in the regulation of various pathways in MDSCs, such as metabolic reprogramming and differentiation (79). Therefore, further studies on MDSCs are warranted in the context of alloHSCT that aim to decipher the roles and interactions of specific metabolism/redox signaling molecules and inflammasome. Those findings could improve our understanding of the finetuning and maintenance of the immunosuppressive functions and differentiation of MDSCs.

To summarize, the generation (67-69) and depletion of MDSCs are gaining interest in the field of research that aims to

\section{REFERENCES}

1. Glucksberg H, Storb R, Fefer A, Buckner CD, Neiman PE, Clift RA, et al. Clinical manifestations of graft-versus-host disease in human recipients of marrow from HL-A-matched sibling donors. Transplantation. (1974) 18:295304. doi: 10.1097/00007890-197410000-00001

2. Le Blanc K, Frassoni F, Ball L, Locatelli F, Roelofs H, Lewis I, et al. Mesenchymal stem cells for treatment of steroid-resistant, severe, acute graft-versus-host disease: a phase II study. Lancet. (2008) 371:157986. doi: 10.1016/S0140-6736(08)60690-X

3. Ringden O, Uzunel M, Rasmusson I, Remberger M, Sundberg B, Lonnies $\mathrm{H}$, et al. Mesenchymal stem cells for treatment of therapy-resistant graft-versus-host disease. Transplantation. (2006) 81:1390-7. doi: 10.1097/01.tp.0000214462.63943.14

4. Hess AD. Modulation of graft-versus-host disease: role of regulatory $\mathrm{T}$ lymphocytes. Biology Blood Marrow Transplant. (2006) 12(Suppl. 2):1321. doi: 10.1016/j.bbmt.2005.11.002

5. Koreth J, Matsuoka K, Kim HT, McDonough SM, Bindra B, Alyea EP III, et al. Interleukin-2 and regulatory T cells in graft-versus-host disease. N Engl J Med. (2011) 365:2055-66. doi: 10.1056/NEJMoa1 108188

6. Chang YJ, Zhao XY, Huang XJ. Strategies for enhancing and preserving anti-leukemia effects without aggravating graft-versus-host disease. Front Immunol. (2018) 9:3041. doi: 10.3389/fimmu.2018.03041 shape the balance between GVHD and GVT. Therefore, MDSC metabolism and the inflammasome pathway should be studied carefully. Results from those studies might determine whether we should consider the administration of repeated infusions of ex vivo expanded MDSCs to modulate GVHD, as is currently routinely performed in cellular therapy with MSC (80).

\section{CONCLUSION}

The present review showed that MDSCs are gaining interest in the context of allo-HSCT. They represent a key regulatory cell type in the inflammatory environment induced by allo-HSCT, particularly in the context of GVHD. Although murine studies have revealed a plethora of mechanisms and pathways that give rise to the generation of MDSCs and their suppressive functions, evidence of these putative mechanisms in humans remains scarce. In the context of allogeneic HSCT, MDSCs have mainly been described as inhibiting the activation, proliferation, and function of $\mathrm{T}$ cells. However, few studies have demonstrated MDSCs interacting with other cells, such as NK cells, iNKT cells, Dendritic Cells, or B cells. Based on this review, we would like to highlight that, to date, M-MDSCs seem to be the most well-described, well-understood MDSC subset in the context of allo-HSCT. The M-MDSC subset is highly conserved between species (mouse and human), has powerful immunosuppressive properties, and could be produced in ex vivo cultures. Future studies on MDSC metabolism and the inflammasome pathway might pave the way for new pharmacologic strategies that can either dampen or enhance MDSC suppressor function according to the clinical context.

\section{AUTHOR CONTRIBUTIONS}

MD'A and AN drafted the manuscript. $\mathrm{CP}, \mathrm{AB}, \mathrm{LB}$, and $\mathrm{MR}$ reviewed and edited the manuscript.

7. Koehn BH, Apostolova P, Haverkamp JM, Miller JS, McCullar V, Tolar $\mathrm{J}$, et al. GVHD-associated, inflammasome-mediated loss of function in adoptively transferred myeloid-derived suppressor cells. Blood. (2015) 126:1621-8. doi: 10.1182/blood-2015-03-634691

8. Gabrilovich DI, Nagaraj S. Myeloid-derived suppressor cells as regulators of the immune system. Nat Rev Immunol. (2009) 9:162-74. doi: 10.1038/nri2506

9. Kusmartsev S, Nagaraj S, Gabrilovich DI. Tumor-associated CD8+ T cell tolerance induced by bone marrow-derived immature myeloid cells. $J$ Immunol. (2005) 175:4583-92. doi: 10.4049/jimmunol.175.7.4583

10. Rodriguez PC, Ochoa AC. Arginine regulation by myeloid derived suppressor cells and tolerance in cancer: mechanisms and therapeutic perspectives. Immunol Rev. (2008) 222:180-91. doi: 10.1111/j.1600-065X.2008.00608.x

11. Gabrilovich DI. Myeloid-derived suppressor cells. Cancer Immunol Res. (2017) 5:3-8. doi: 10.1158/2326-6066.CIR-16-0297

12. Mandruzzato S, Brandau S, Britten CM, Bronte V, Damuzzo V, Gouttefangeas $\mathrm{C}$, et al. Toward harmonized phenotyping of human myeloid-derived suppressor cells by flow cytometry: results from an interim study. Cancer Immunol Immunother. (2016) 65:161-9. doi: 10.1007/s00262-015-1782-5

13. An B, Lim JY, Jeong S, Shin DM, Choi EY, Min CK, et al. CD1d is a novel cellsurface marker for human monocytic myeloid-derived suppressor cells with $\mathrm{T}$ cell suppression activity in peripheral blood after allogeneic hematopoietic stem cell transplantation. Biochem Biophys Res Commun. (2018) 495:51925. doi: 10.1016/j.bbrc.2017.11.010 
14. Roder JC, Duwe AK, Bell DA, Singhal SK. Immunological senescence. I. The role of suppressor cells. Immunology. (1978) 35:837-47.

15. Subiza JL, Vinuela JE, Rodriguez R, Gil J, Figueredo MA, De La Concha EG. Development of splenic natural suppressor (NS) cells in Ehrlich tumorbearing mice. Int J Cancer. (1989) 44:307-14. doi: 10.1002/ijc.2910440220

16. Noga SJ, Wagner JE, Horwitz LR, Donnenberg AD, Santos GW, Hess AD. Characterization of the natural suppressor cell population in adult rat bone marrow. J Leukoc Biol. (1988) 43:279-87. doi: 10.1002/jlb.43.3.279

17. Oseroff A, Okada S, Strober S. Natural suppressor (NS) cells found in the spleen of neonatal mice and adult mice given total lymphoid irradiation (TLI) express the null surface phenotype. J Immunol. (1984) 132:101-10.

18. Sykes M, Sharabi Y, Sachs DH. Natural suppressor cells in spleens of irradiated, bone marrow-reconstituted mice and normal bone marrow: lack of Sca-1 expression and enrichment by depletion of Mac1-positive cells. Cell Immunol. (1990) 127:260-74. doi: 10.1016/0008-8749(90)90131-A

19. Holda JH, Maier T, Claman HN. Graft-vs-host reactions (GVHR) across minor murine histocompatibility barriers. I. Impairment of mitogen responses and suppressor phenomena. J Immunol. (1985) 134:1397-402.

20. Maier T, Holda JH, Claman HN. Graft-vs-host reactions (GVHR) across minor murine histocompatibility barriers. II. Development of natural suppressor cell activity. J Immunol. (1985) 135:1644-51.

21. Sykes M, Eisenthal A, Sachs DH. Mechanism of protection from graft-vs-host disease in murine mixed allogeneic chimeras. I. Development of a null cell population suppressive of cell-mediated lympholysis responses and derived from the syngeneic bone marrow component. J Immunol. (1988) 140:2903-11.

22. Johnson BD, Hanke CA, Becker EE, Truitt RL. Sca1(+)/Mac1(+) nitric oxideproducing cells in the spleens of recipients early following bone marrow transplant suppress T cell responses in vitro. Cell Immunol. (1998) 189:14959. doi: 10.1006/cimm.1998.1373

23. Ghansah T, Paraiso KH, Highfill S, Desponts C, May S, McIntosh JK, et al. Expansion of myeloid suppressor cells in SHIP-deficient mice represses allogeneic $\mathrm{T}$ cell responses. J Immunol. (2004) 173:732430. doi: 10.4049/jimmunol.173.12.7324

24. Luyckx A, Schouppe E, Rutgeerts O, Lenaerts C, Koks C, Fevery S, et al. Subset characterization of myeloid-derived suppressor cells arising during induction of BM chimerism in mice. Bone Marrow Transplant. (2012) 47:98592. doi: 10.1038/bmt.2011.207

25. Wang D, Yu Y, Haarberg K, Fu J, Kaosaard K, Nagaraj S, et al. Dynamic change and impact of myeloid-derived suppressor cells in allogeneic bone marrow transplantation in mice. Biology Blood Marrow Transplant. (2013) 19:692-702. doi: 10.1016/j.bbmt.2013.01.008

26. Billiau AD, Fevery S, Rutgeerts O, Landuyt W, Waer M. Transient expansion of Mac1+Ly6-G+Ly6-C+ early myeloid cells with suppressor activity in spleens of murine radiation marrow chimeras: possible implications for the graft-versus-host and graft-versus-leukemia reactivity of donor lymphocyte infusions. Blood. (2003) 102:740-8. doi: 10.1182/blood-2002-06-1833

27. Hoechst B, Ormandy LA, Ballmaier M, Lehner F, Kruger C, Manns $\mathrm{MP}$, et al. A new population of myeloid-derived suppressor cells in hepatocellular carcinoma patients induces CD4(+)CD25(+)Foxp3(+) T cells. Gastroenterology. (2008) 135:234-43. doi: 10.1053/j.gastro.2008.03.020

28. Mandruzzato S, Solito S, Falisi E, Francescato S, Chiarion-Sileni V, Mocellin $\mathrm{S}$, et al. IL4Ralpha+ myeloid-derived suppressor cell expansion in cancer patients. J Immunol. (2009) 182:6562-8. doi: 10.4049/jimmunol.0803831

29. Zea AH, Rodriguez PC, Atkins MB, Hernandez C, Signoretti S, Zabaleta J, et al. Arginase-producing myeloid suppressor cells in renal cell carcinoma patients: a mechanism of tumor evasion. Cancer Res. (2005) 65:30448. doi: 10.1158/0008-5472.CAN-04-4505

30. Bingisser RM, Tilbrook PA, Holt PG, Kees UR. Macrophage-derived nitric oxide regulates $\mathrm{T}$ cell activation via reversible disruption of the Jak3/STAT5 signaling pathway. J Immunol. (1998) 160:5729-34.

31. Fischer TA, Palmetshofer A, Gambaryan S, Butt E, Jassoy C, Walter U, et al. Activation of cGMP-dependent protein kinase Ibeta inhibits interleukin 2 release and proliferation of $\mathrm{T}$ cell receptor-stimulated human peripheral $\mathrm{T}$ cells. J Biol Chem. (2001) 276:5967-74. doi: 10.1074/jbc.M009781200

32. Mazzoni A, Bronte V, Visintin A, Spitzer JH, Apolloni E, Serafini P, et al. Myeloid suppressor lines inhibit $\mathrm{T}$ cell responses by an NO-dependent mechanism. J Immunol. (2002) 168:689-95. doi: 10.4049/jimmunol.168.2.689

33. Macphail SE, Gibney CA, Brooks BM, Booth CG, Flanagan BF, Coleman JW. Nitric oxide regulation of human peripheral blood mononuclear cells: critical time dependence and selectivity for cytokine versus chemokine expression. $J$ Immunol. (2003) 171:4809-15. doi: 10.4049/jimmunol.171.9.4809

34. Serafini P, Meckel K, Kelso M, Noonan K, Califano J, Koch W, et al. Phosphodiesterase-5 inhibition augments endogenous antitumor immunity by reducing myeloid-derived suppressor cell function. J Exp Med. (2006) 203:2691-702. doi: 10.1084/jem.20061104

35. D'Aveni M, Rossignol J, Coman T, Sivakumaran S, Henderson S, Manzo T, et al. G-CSF mobilizes CD34+ regulatory monocytes that inhibit graft-versus-host disease. Sci Transl Med. (2015) 7:281ra42. doi: 10.1126/scitranslmed.3010435

36. Rodriguez PC, Quiceno DG, Ochoa AC. L-arginine availability regulates T-lymphocyte cell-cycle progression. Blood. (2007) 109:1568-73. doi: 10.1182/blood-2006-06-031856

37. Highfill SL, Rodriguez PC, Zhou Q, Goetz CA, Koehn BH, Veenstra $\mathrm{R}$, et al. Bone marrow myeloid-derived suppressor cells (MDSCs) inhibit graft-versus-host disease (GVHD) via an arginase-1-dependent mechanism that is up-regulated by interleukin-13. Blood. (2010) 116:5738-47. doi: 10.1182/blood-2010-06-287839

38. Joo YD, Lee SM, Lee SW, Lee WS, Lee SM, Park JK, et al. Granulocyte colony-stimulating factor-induced immature myeloid cells inhibit acute graft-versus-host disease lethality through an indoleamine dioxygenase-independent mechanism. Immunology. (2009) 128(Suppl. 1):e632-40. doi: 10.1111/j.1365-2567.2009.03048.x

39. Lewkowicz N, Klink M, Mycko MP, Lewkowicz P. NeutrophilCD4+CD25+ $\mathrm{T}$ regulatory cell interactions: a possible new mechanism of infectious tolerance. Immunobiology. (2013) 218:455-64. doi: 10.1016/j.imbio.2012.05.029

40. Yadav M, Stephan S, Bluestone JA. Peripherally induced tregs - role in immune homeostasis and autoimmunity. Front Immunol. (2013) 4:232. doi: 10.3389/fimmu.2013.00232

41. MacDonald KP, Rowe V, Clouston AD, Welply JK, Kuns RD, Ferrara JL, et al. Cytokine expanded myeloid precursors function as regulatory antigenpresenting cells and promote tolerance through IL-10-producing regulatory $\mathrm{T}$ cells. J Immunol. (2005) 174:1841-50. doi: 10.4049/jimmunol.174.4.1841

42. Perobelli SM, Mercadante AC, Galvani RG, Goncalves-Silva T, Alves AP, Pereira-Neves A, et al. G-CSF-Induced suppressor IL-10+ neutrophils promote regulatory $\mathrm{T}$ cells that inhibit graft-versushost disease in a long-lasting and specific way. J Immunol. (2016) 197:3725-34. doi: 10.4049/jimmunol.1502023

43. van der Merwe M, Abdelsamed HA, Seth A, Ong T, Vogel P, Pillai AB. Recipient myeloid-derived immunomodulatory cells induce $\mathrm{PD}-1$ ligand-dependent donor CD4+Foxp3+ regulatory $\mathrm{T}$ cell proliferation and donor-recipient immune tolerance after murine nonmyeloablative bone marrow transplantation. J Immunol. (2013) 191:5764-76. doi: 10.4049/jimmunol.1302191

44. Lim JY, Ryu DB, Park MY, Lee SE, Park G, Kim TG, et al. Ex vivo generated human cord blood myeloid-derived suppressor cells attenuate murine chronic graft-versus-host diseases. Biol Blood Marrow Transplant. (2018) 24:238196. doi: 10.1016/j.bbmt.2018.07.004

45. Luyckx A, Schouppe E, Rutgeerts O, Lenaerts C, Fevery S, Devos T, et al. G-CSF stem cell mobilization in human donors induces polymorphonuclear and mononuclear myeloid-derived suppressor cells. Clin Immunol. (2012) 143:83-7. doi: 10.1016/j.clim.2012.01.011

46. Vendramin A, Gimondi S, Bermema A, Longoni P, Rizzitano S, Corradini $\mathrm{P}$, et al. Graft monocytic myeloid-derived suppressor cell content predicts the risk of acute graft-versus-host disease after allogeneic transplantation of granulocyte colony-stimulating factor-mobilized peripheral blood stem cells. Biol Blood Marrow Transplant. (2014) 20:2049-55. doi: 10.1016/j.bbmt.2014.09.011

47. Wang K, Lv M, Chang YJ, Zhao XY, Zhao XS, Zhang YY, et al. Early myeloid-derived suppressor cells (HLA-DR(-)/(low)CD33(+)CD16(-)) expanded by granulocyte colony-stimulating factor prevent acute graftversus-host disease (GVHD) in humanized mouse and might contribute to lower GVHD in patients post allo-HSCT. J Hematol Oncol. (2019) 12:31. doi: 10.1186/s13045-019-0710-0

48. Lv M, Zhao XS, Hu Y, Chang YJ, Zhao XY, Kong Y, et al. Monocytic and promyelocytic myeloid-derived suppressor cells may contribute to G-CSFinduced immune tolerance in haplo-identical allogeneic hematopoietic stem cell transplantation. Am J Hematol. (2015) 90:E9-16. doi: 10.1002/ajh.23865 
49. Fan Q, Liu H, Liang X, Yang T, Fan Z, Huang F, et al. Superior GVHD-free, relapse-free survival for G-BM to G-PBSC grafts is associated with higher MDSCs content in allografting for patients with acute leukemia. J Hematol Oncol. (2017) 10:135. doi: 10.1186/s13045-017-0503-2

50. Mougiakakos D, Jitschin R, von Bahr L, Poschke I, Gary R, Sundberg B, et al. Immunosuppressive CD14+HLA-DRlow/neg IDO+ myeloid cells in patients following allogeneic hematopoietic stem cell transplantation. Leukemia. (2013) 27:377-88. doi: 10.1038/leu.2012.215

51. Guan Q, Blankstein AR, Anjos K, Synova O, Tulloch M, Giftakis A, et al. Functional myeloid-derived suppressor cell subsets recover rapidly after allogeneic hematopoietic stem/progenitor cell transplantation. Biol Blood Marrow Transplant. (2015) 21:1205-14. doi: 10.1016/j.bbmt.2015.04.015

52. Kim TW, Park SS, Lim JY, Min GJ, Park S, Jeon YW, et al. Predictive role of circulating immune cell subtypes early after allogeneic hematopoietic stem cell transplantation in patients with acute leukemia. In J Stem Cells. (2018) 12:73-83. doi: 10.15283/ijsc18094

53. Lee SE, Lim JY, Kim TW, Jeon YW, Yoon JH, Cho BS, et al. Matrix metalloproteinase-9 in monocytic myeloid-derived suppressor cells correlate with early infections and clinical outcomes in allogeneic hematopoietic stem cell transplantation. Biol Blood Marrow Transplant. (2018) 24:3242. doi: 10.1016/j.bbmt.2017.08.017

54. Rieber N, Wecker I, Neri D, Fuchs K, Schafer I, Brand A, et al. Extracorporeal photopheresis increases neutrophilic myeloid-derived suppressor cells in patients with GvHD. Bone Marrow Transplant. (2014) 49:545-52. doi: 10.1038/bmt.2013.236

55. Wang L, Ni M, Huckelhoven-Krauss A, Sellner L, Hoffmann JM, Neuber B, et al. Modulation of B cells and homing marker on NK cells through extracorporeal photopheresis in patients with steroid-refractory/resistant graft-vs.-host disease without hampering anti-viral/anti-leukemic effects. Front Immunol. (2018) 9:2207. doi: 10.3389/fimmu.2018.02207

56. Zhang J, Chen HM, Ma G, Zhou Z, Raulet D, Rivera AL, et al. The mechanistic study behind suppression of GVHD while retaining GVL activities by myeloid-derived suppressor cells. Leukemia. (2019) 33:207889. doi: 10.1038/s41375-019-0394-Z

57. Edinger M, Hoffmann P, Ermann J, Drago K, Fathman CG, Strober S, et al. $\mathrm{CD} 4+\mathrm{CD} 25+$ regulatory $\mathrm{T}$ cells preserve graft-versus-tumor activity while inhibiting graft-versus-host disease after bone marrow transplantation. Nat Med. (2003) 9:1144-50. doi: 10.1038/nm915

58. Stokes J, Hoffman EA, Zeng Y, Larmonier N, Katsanis E. Post-transplant bendamustine reduces GvHD while preserving $\mathrm{GvL}$ in experimental haploidentical bone marrow transplantation. Br J Haematol. (2016) 174:10216. doi: 10.1111/bjh. 14034

59. Shuyu E, Seth A, Vogel P, Sommers M, Ong T, Pillai AB. Bidirectional immune tolerance in nonmyeloablative MHC-mismatched BMT for murine betathalassemia. Blood. (2017) 129:3017-30. doi: 10.1182/blood-2016-03-704387

60. Kittang AO, Kordasti S, Sand KE, Costantini B, Kramer AM, Perezabellan P, et al. Expansion of myeloid derived suppressor cells correlates with number of $\mathrm{T}$ regulatory cells and disease progression in myelodysplastic syndrome. Oncoimmunology. (2016) 5:e1062208. doi: 10.1080/2162402X.2015.1062208

61. Bizymi N, Bjelica S, Kittang AO, Mojsilovic S, Velegraki M, Pontikoglou $\mathrm{C}$, et al. Myeloid-derived suppressor cells in hematologic diseases: promising biomarkers and treatment targets. HemaSphere. (2019) 3:e168. doi: 10.1097/HS9.0000000000000168

62. Tumino N, Besi F, Di Pace AL, Mariotti FR, Merli P, Li Pira G, et al. PMN-MDSC are a new target to rescue graft-versus-leukemia activity of NK cells in haplo-HSC transplantation. Leukemia. (2020) 34:9327. doi: 10.1038/s41375-019-0585-7

63. Schneidawind C, Jahnke S, Schober-Melms I, Schumm M, Handgretinger R, Faul C, et al. G-CSF administration prior to donor lymphocyte apheresis promotes anti-leukaemic effects in allogeneic HCT patients. Br J Haematol. (2019) 186:60-71. doi: 10.1111/bjh.15881

64. Yin J, Wang C, Huang M, Mao X, Zhou J, Zhang Y. Circulating CD14(+) HLA-DR(-/low) myeloid-derived suppressor cells in leukemia patients with allogeneic hematopoietic stem cell transplantation: novel clinical potential strategies for the prevention and cellular therapy of graft-versus-host disease. Cancer Med. (2016) 5:1654-69. doi: 10.1002/cam4.688

65. Morecki S, Gelfand Y, Yacovlev E, Eizik O, Shabat Y, Slavin S. CpGinduced myeloid CD11b+Gr-1+ cells efficiently suppress $\mathrm{T}$ cell-mediated immunoreactivity and graft-versus-host disease in a murine model of allogeneic cell therapy. Biol Blood Marrow Transplant. (2008) 14:97384. doi: 10.1016/j.bbmt.2008.06.018

66. Messmann JJ, Reisser T, Leithauser F, Lutz MB, Debatin KM, Strauss G. In vitro-generated MDSCs prevent murine GVHD by inducing type $2 \mathrm{~T}$ cells without disabling antitumor cytotoxicity. Blood. (2015) 126:113848. doi: 10.1182/blood-2015-01-624163

67. Park MY, Lim BG, Kim SY, Sohn HJ, Kim S, Kim TG. GM-CSF promotes the expansion and differentiation of cord blood myeloid-derived suppressor cells, which attenuate xenogeneic graft-vs.-host disease. Front Immunol. (2019) 10:183. doi: 10.3389/fimmu.2019.00183

68. Casacuberta-Serra S, Pares M, Golbano A, Coves E, Espejo C, Barquinero J. Myeloid-derived suppressor cells can be efficiently generated from human hematopoietic progenitors and peripheral blood monocytes. Immunology Cell Biol. (2017) 95:538-48. doi: 10.1038/icb.2017.4

69. Janikashvili N, Trad M, Gautheron A, Samson M, Lamarthee B, Bonnefoy F, et al. Human monocyte-derived suppressor cells control graft-versushost disease by inducing regulatory forkhead box protein 3-positive CD8+ T lymphocytes. J Allergy Clin Immunol. (2015) 135:1614-24 e4. doi: 10.1016/j.jaci.2014.12.1868

70. Lim JY, Lee YK, Lee SE, Ju JM, Eom KS, Kim YJ, et al. MyD88 in donor bone marrow cells is critical for protection from acute intestinal graft-vs.-host disease. Mucosal Immunol. (2016) 9:730-43. doi: 10.1038/mi.2015.96

71. Lee SE, Lim JY, Ryu DB, Kim TW, Park SS, Jeon YW, et al. Alteration of the intestinal microbiota by broad-spectrum antibiotic use correlates with the occurrence of intestinal graft-versus-host disease. Biology Blood Marrow Transplant. (2019) 25:1933-43. doi: 10.1016/j.bbmt.2019.06.001

72. Ferrari D, Pizzirani C, Adinolfi E, Lemoli RM, Curti A, Idzko M, et al. The P2X7 receptor: a key player in IL-1 processing and release. J Immunol. (2006) 176:3877-83. doi: 10.4049/jimmunol.176.7.3877

73. Wilhelm K, Ganesan J, Muller T, Durr C, Grimm M, Beilhack A, et al. Graftversus-host disease is enhanced by extracellular ATP activating P2X7R. Nat Med. (2010) 16:1434-8. doi: 10.1038/nm.2242

74. Jankovic D, Ganesan J, Bscheider M, Stickel N, Weber FC, Guarda G, et al. The Nlrp3 inflammasome regulates acute graft-versus-host disease. J Exp Med. (2013) 210:1899-910. doi: 10.1084/jem.20130084

75. Lim JY, Lee YK, Lee SE, Ju JM, Park G, Choi EY, et al. Attenuation of hepatic graft-versus-host disease in allogeneic recipients of MyD88-deficient donor bone marrow. Immune Netw. (2015) 15:125-34. doi: 10.4110/in.2015.15.3.125

76. Koehn BH, Saha A, McDonald-Hyman C, Loschi M, Thangavelu G, Ma L, et al. Danger-associated extracellular ATP counters MDSC therapeutic efficacy in acute GVHD. Blood. (2019) 134:1670-82. doi: 10.1182/blood.2019001950

77. Zhou R, Yazdi AS, Menu P, Tschopp J. A role for mitochondria in NLRP3 inflammasome activation. Nature. (2011) 469:2215. doi: 10.1038/nature09663

78. Sarhan D, Wang J, Sunil Arvindam U, Hallstrom C, Verneris MR, Grzywacz $\mathrm{B}$, et al. Mesenchymal stromal cells shape the MDS microenvironment by inducing suppressive monocytes that dampen NK cell function. JCI Insight. (2020) 5:e130155. doi: 10.1172/jci.insight.130155

79. Ohl K, Fragoulis A, Klemm P, Baumeister J, Klock W, Verjans E, et al. Nrf2 Is a central regulator of metabolic reprogramming of myeloidderived suppressor cells in steady state and sepsis. Front Immunol. (2018) 9:1552. doi: 10.3389/fimmu.2018.01552

80. Bader P, Kuci Z, Bakhtiar S, Basu O, Bug G, Dennis M, et al. Effective treatment of steroid and therapy-refractory acute graft-versushost disease with a novel mesenchymal stromal cell product (MSC FFM). Bone Marrow Transplant. (2018) 53:852-62. doi: 10.1038/s41409-01 $8-0102-\mathrm{z}$

Conflict of Interest: The authors declare that the research was conducted in the absence of any commercial or financial relationships that could be construed as a potential conflict of interest.

Copyright (c) 2020 D’Aveni, Notarantonio, Bertrand, Boulangé, Pochon and Rubio. This is an open-access article distributed under the terms of the Creative Commons Attribution License (CC BY). The use, distribution or reproduction in other forums is permitted, provided the original author(s) and the copyright owner(s) are credited and that the original publication in this journal is cited, in accordance with accepted academic practice. No use, distribution or reproduction is permitted which does not comply with these terms. 